\title{
Genome-wide interplay between chromatin and the transcription machinery
}

\author{
B Franklin Pugh \\ From Epigenetics and Chromatin: Interactions and processes \\ Boston, MA, USA. 11-13 March 2013
}

\begin{abstract}
With the advent of high throughput and high resolution genome-wide protein-DNA detection assays, the interrelationships between chromatin and the transcription machinery are now becoming clearer. Here I will discuss our recent findings using MNase ChIP-seq to map nucleosome positions, and an ultra-high resolution mapping technique called ChIP-exo that we recently developed (Rhee and Pugh, Cell 2011 14:1408). What is apparent from these studies is the following: 1) transcription factors bind to many more locations in the genome than previously appreciated. 2) transcription complexes form at the interface between nucleosomes and nucleosome-free promoter regions. 3) Chromatin remodeling complexes target specific nucleosome positions, working in concert to organize nucleosomes at the beginning and end of genes. Many remodeler subunits interact asymmetrically with the nucleosome core across the genome, which may be important for the directional passage of RNA polymerase II.
\end{abstract}

Published: 18 March 2013

doi:10.1186/1756-8935-6-S1-019

Cite this article as: Pugh: Genome-wide interplay between chromatin and the transcription machinery. Epigenetics \& Chromatin 2013 6(Suppl 1): 019.
Penn State University, USA

(c) 2013 Pugh; licensee BioMed Central Ltd. This is an Open Access article distributed under the terms of the Creative Commons Attribution License (http://creativecommons.org/licenses/by/2.0), which permits unrestricted use, distribution, and reproduction in any medium, provided the original work is properly cited.
Submit your next manuscript to BioMed Central and take full advantage of:

- Convenient online submission

- Thorough peer review

- No space constraints or color figure charges

- Immediate publication on acceptance

- Inclusion in PubMed, CAS, Scopus and Google Scholar

- Research which is freely available for redistribution 